\title{
Nursing diagnoses of newborns with sepsis in a Neonatal Intensive Care Unit
}

\author{
Ana Paula de Souza Santos ${ }^{1}$ \\ Maria de Lourdes Costa da Silva² \\ Nilba Lima de Souza ${ }^{3}$ \\ Gabriela Miranda Mota ${ }^{4}$ \\ Débora Feitosa de França ${ }^{5}$
}

Objectives: to elaborate the Nursing Diagnoses of newborns with sepsis in a neonatal intensive care unit and characterize the profile of the neonates and their mothers. Method: a crosssectional and quantitative study, with a sample of 41 neonates. A physical examination and consultation of the hospital records were undertaken, using an instrument. The elaboration of the Nursing Diagnoses followed a process of diagnostic inference and was based on the North American Nursing Diagnosis Association 2012-2014. Results: the mothers were around 25 years old, had a low average number of pre-natal consultations, and various complications during the pregnancy; and the newborns were predominantly premature and with very low birth weights. Five Nursing Diagnoses predominated, and all the neonates presented Risk of Shock and Risk of fluid volume imbalance. Conclusion: the Nursing Diagnoses of the neonates with sepsis can guide the formulating of specific assistential plans. The study contributes to the generation of new knowledge and found various relationships between the Nursing Diagnoses and the variables selected in the characterization of the neonates, which deserve to be elucidated in greater detail based on further research on the issue.

Descriptors: Nursing Diagnosis; Infant, Newborn; Sepsis; Neonatal Nursing.

\footnotetext{
${ }^{1}$ RN, Specialist in Neonatal Intensive Care, Universidade Federal do Rio Grande do Norte, Natal, RN, Brazil.

${ }^{2}$ Doctoral student, Universidade Federal do Rio Grande do Norte, Natal, RN, Brazil. Assistant Professor, Departamento de Enfermagem, Universidade Federal do Rio Grande do Norte, Natal, RN, Brazil.

${ }^{3}$ PhD, Professor, Departamento de Enfermagem, Universidade Federal do Rio Grande do Norte, Natal, RN, Brazil.

${ }^{4}$ RN, Specialist in Neonatal Intensive Care, Hospital da Polícia Militar Coronel Pedro Germano, Natal, RN, Brazil.

${ }^{5}$ RN, Maternidade Escola Januário Cicco, Universidade Federal do Rio Grande do Norte, Natal, RN, Brasil.
}

Corresponding Author:

Ana Paula de Souza Santos

Rua Dom Bosco, 758

Bairro: Emaús

CEP: 59148-450, Parnamirim, RN, Brasil

E-mail: anasouzaenf@gmail.com
Copyright () 2014 Revista Latino-Americana de Enfermagem This is an Open Access article distributed under the terms of the Creative Commons Attribution Non-Commercial License (CC BY-NC).

This license lets others distribute, remix, tweak, and build upon your work non-commercially, and although their new works must also acknowledge you and be non-commercial, they don't have to license their derivative works on the same terms. 


\section{Introduction}

Neonatal sepsis, or Primary Infection of the Bloodstream (BSI) is a clinical syndrome characterized by a systemic inflammatory response, with or without evidence of a suspected or confirmed infection. It is one of the more frequent infectious pictures in the neonatal period, and is the one which most raises morbidity and mortality ${ }^{(1-2)}$.

BSI can develop as early-onset, when diagnosed in the first 48 hours of the newborn's (NB) life and in the presence of a perinatal risk factor for infection. In the late-onset form, the diagnosis is made after the first 48 hours, and the incidence is related to the care environment, notably in the Neonatal Intensive Care Unit (NICU) ${ }^{(3)}$.

The Nurse with the NB with this illness is, often, the professional who observes the first signs and symptoms of the infection, which makes her important for early diagnosis and intervention, by advocating in the name of the child and ensuring timely diagnostic complementation and empirical antibiotic therapy ${ }^{(4-5)}$.

In this aspect of the care, the Systematization of Nursing Care (SNC) presupposes the organization of the work regarding the method, personnel and instruments, and makes possible the operationalization of the Nursing Process, a methodological tool made up of five interrelated stages: Nursing History, Nursing Diagnosis (ND), Planning, Implementation and Evaluation ${ }^{(6-7)}$. Through the ND, the nurse uses clinical reasoning and judgment and concludes the surveying of data referent to the patient's state of health, allowing the standardization and individualization of the care $^{(8)}$.

After intensive searching of the literature available, only 11 works were detected whose focus was on the NDs in Neonatology. The Nursing studies regarding sepsis are limited to few publications ${ }^{(4-5,9)}$. Only two works address the NDs of NBs with specific illnesses, there being no studies regarding the NDs of neonates with sepsis.

The undertaking of the study on the abovementioned issue is based on the point of view that the NDs consist of knowledge which is relevant for the guiding of the decision-making of the nurses who care for these patients. The research is also justified because it aims to meet the compulsoriness of SNC in line with legislation(7) and, thus, can contribute to the implementation of SNC in NICU, to the improvement of the care, and to the reduction of mortality from neonatal sepsis in the long term. Emphasis is given to the importance of the research for nursing because it integrates the range of studies linked to the NDs, given that the operationalization of diagnostic systems contributes to the construction of accurate clinical reasoning, facilitates communication between the health professionals, and allows the development of the profession ${ }^{(10-11)}$.

Based on this context, the study aimed to elaborate the NDs of newborns with sepsis in a NICU, according to the North American Nursing Diagnosis Association (NANDA-I) 2012-2014(12) and to characterize the profile of the mothers and the affected neonates.

\section{Method}

A cross-sectional and quantitative study was undertaken in the Neonatal ICU of the Januário Cicco Maternity School, a state center of excellence in highrisk maternal-infant care.

The inclusion criteria for the sample were: neonates interned in the NICU with a diagnosis of sepsis during the data collection period, May - August 2012. The NBs who met these criteria were recruited through consecutive convenience, by listing consecutively all the population accessible. The exclusion criteria were: neonates with congenital heart defect, and those for whom the diagnosis of the illness was ruled out. The sample calculation resulted in 41 neonates, with a confidence interval of $95 \%$ (CI 95\%) and a margin of error of $5 \%$.

For data collection, a complete physical examination of the NB was used, in line with the recommended techniques and neonatal specific characteristics ${ }^{(2,13)}$, and consultation of the hospital records.

The data collected was guided by an instrument developed based on another model applied in neonatology and already validated in the literature ${ }^{(14)}$. The form is composed of two main parts: the first contains maternal characteristics (identification, sociodemographic data and obstetric data) and neonatal characteristics (identification, occurrences of the birth, birth data and anthropometric data); the second has information related to the NB's nursing history, which includes the psycho-biological needs (oxygenation, hydration, nutrition, elimination, sleep and rest, motility, shelter, skin and mucous membrane integrity, physical integrity, thermal, neurological, hydro-electrolytic and immunological regulation, perception, environment) and the psycho-social needs (safety, love, communication).

Subsequently, the instrument was submitted for content validation by four nurses who are specialists in neonatal care, in hospital infections, and/or in nursing 
diagnoses. Their recommendations were accepted and reflected in the instrument's improvement. The pretest was undertaken with septic newborns from another institution similar to the place of the study and did not result in alterations to the form.

So as to characterize the mothers, the following variables were chosen: where they were from, marital status, age, number of pre-natal consultations attended, and complications during the pregnancy. And to characterize the neonates: place of birth, sex, type of birth, gestational age (GA), weight at birth, Apgar scores, need for resuscitation at birth, the next event (discharge from NICU, transference to another hospital, or death) and the types of clinical manifestations of the neonatal sepsis. These variables were defined as independent and allowed the identification of the defining characteristics, the related factors, and the risk factors which involve the NDs elaborated, considered dependent variables.

The process of the elaboration of the NDs followed the stages of the process of reasoning and diagnostic inference proposed in the literature(6): analysis of the grouping of indicators; lists of suspected problems; discarding of similar diagnoses; choice of more specific diagnostic labels; declaration of the problems and their causes; and identification of strong points, resources and areas of improvement. After all the NDs were formulated, the process was followed for adaptation of the nomination, supported in the NANDA-I 2012-2014 Taxonomy ${ }^{(12)}$.

All the data collected was organized in databases constructed in the Excel software and was submitted to descriptive statistics using the Statistical Package for the Social Sciences (SPSS) version 20.

The descriptive analysis of the quantitative variables involved calculations of the mean, the median and standard deviation, and that of the categorical variables was undertaken through absolute and relative frequencies, with a level of significance of $5 \%$ and CI $95 \%$. The frequency relationships between the NDs and the variables listed in the characterization of the neonates were studied.

The study had prior approval by the Research Ethics Committee of the Onofre Lopes University Hospital, under Decision 16576, and received authorization from the parents and guardians of the NBs, through signing the Terms of Free and Informed Consent.

\section{Results}

With relation to the maternal characteristics, a little over half were from the rural areas of the State of Rio
Grande do Norte (RN) (58.5\%). The majority were in a stable relationship (87.8\%). The mean age was 24.9 ( $S D \pm 6.7$ years), while $70.7 \%$ were aged between 19 and 35 years old.

There was a mean of 4.4 pre-natal consultations $(\mathrm{SD} \pm 2.3)$ and only $19.5 \%$ had attended more than six. The recurrent gestational complications were Urinary Tract Infection (UTI) (31.7\%), PregnancySpecific Hypertensive Disorders (PSHD) (29.2\%) and amniotic membrane rupture (24.4\%), which had a mean equivalent to 37.4 hours \pm 29 hours. A history of drug use was ascertained in $17.1 \%$, namely crack cocaine. Genital infections occurred in $12.2 \%$, such as chorioamnionitis, candidiasis, and bacterial vaginosis. Syphilis affected $14.6 \%$ of the women, most of whom received no or inadequate treatment.

Regarding the neonatal characteristics, $95.1 \%$ of the NBs were born in the locale of the study; and there was no significant predominance in the sample in relation to females $(46.3 \%)$ or males $(53.7 \%)$ and to the type of birth, either vaginal $(48.8 \%)$ or surgical (51.2\%). The mean GA was 31 weeks (SD \pm 5 weeks, 2 days), in which $51.2 \%$ of the premature babies had between 23 and 30 weeks of GA, making up $78 \%$ of the pre-term births. The mean weight at birth was 1475 $\mathrm{g}$, totalling $85.4 \%$ of the NBs with low weight at birth (LBWN); and weight $\leq 1500 \mathrm{~g}$ represented $56.1 \%$ of this total. The Apgar score in the 5 th minute had a mean of $7.2(\mathrm{SD} \pm 2)$.

Little over half of the neonates needed tracheal intubation (53.7\%) as a resuscitation manoeuvre. Most of the sample progressed to discharge from the NICU to the shared accommodation (75.6\%) and six cases died $(14.6 \%)$.

Figure 1 shows the clinical manifestations of the sepsis presented by the NBs.

Table 1 shows the measurements of central tendency and of dispersion of the total of the NBs, the defining characteristics, the related factors and the risk factors detected in the NBs with BSI.

It should be clarified that the presentation of the NDs and the discussion about them is limited only to those registered in Table 2, which presents the distribution of the thirteen NDs with percentages over $20 \%$. Emphasis is placed on the first five NDs, observed in more than $60 \%$ of the NBs. After Table 2, Table 3 is shown, with the percentages of the defining characteristics, related factors, and risk factors of the five prevalent NDs. 


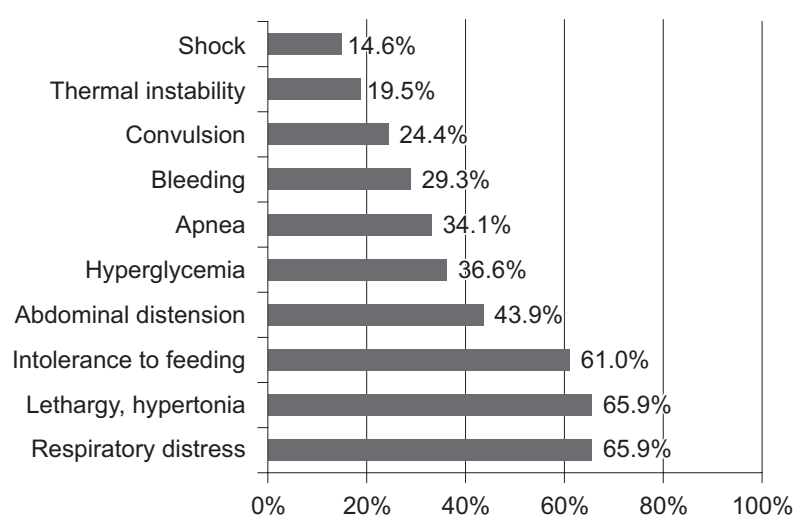

Figure 1 - Distribution of the clinical manifestations of neonatal sepsis in 41 newborns. Natal, RN, Brazil, 2012

Table 1 - Measurements of the Nursing Diagnoses, defining characteristics, related factors and risk factors of 41 NBs with sepsis, according to NANDA-I 2012-2014, Natal, RN, Brazil, 2012

\begin{tabular}{|c|c|c|c|c|c|}
\hline Variables & Total & Mean & Standard Deviation & Median & $\begin{array}{c}\text { Confidence Interval } \\
95 \%\end{array}$ \\
\hline Nursing Diagnoses & 31 & 8.4 & 3.1 & 8 & $7.5-9.4$ \\
\hline Defining Characteristics & 62 & 8.3 & 4.8 & 7 & $6.8-9.8$ \\
\hline Related Factors & 37 & 4.2 & 3.3 & 3 & $3.2-5.3$ \\
\hline Risk Factors & 40 & 5.7 & 4.5 & 4 & $4.2-7.1$ \\
\hline
\end{tabular}

Table 2 - Nursing Diagnoses of 41 NBs with sepsis, according to NANDA-I 2012-2014, Natal, RN, Brazil, 2012

\begin{tabular}{lccc}
\hline \multicolumn{1}{c}{ Nursing Diagnoses } & $\mathbf{n}$ & $\%$ & Confidence Interval 95\% \\
\hline 1. Risk of shock & 41 & 100 & $91.4-100$ \\
2. Risk of fluid volume imbalance & 41 & 100 & $91.4-100$ \\
3. Gastrointestinal motility dysfunction & 32 & 78.0 & $63.3-88.0$ \\
4. Neonatal jaundice & 26 & 63.4 & $48.1-76.4$ \\
5. Impaired gaseous Exchange & 25 & 61.0 & $45.7-74.3$ \\
6. Inefficient respiratory pattern & 22 & 53.7 & $38.7-67.9$ \\
7. Risk of bleeding & 22 & 53.7 & $38.7-67.9$ \\
8. Risk of ineffective renal perfusion & 22 & 53.7 & $38.7-67.9$ \\
9. Risk of developmental delays & 19 & 46.3 & $32.1-61.3$ \\
10. Reduced cardiac output & 13 & 31.7 & $19.6-47.0$ \\
11. Hypothermia & 10 & 24.4 & $13.8-39.3$ \\
12. Risk of impaired bonding & 10 & 24.4 & $13.8-39.3$ \\
13. Ineffective airway clearance & 9 & 22.0 & $12.0-36.7$ \\
\hline
\end{tabular}

Table 3 - Frequent Nursing Diagnoses and defining characteristics, related factors and risk factors of 41 NBs with sepsis, NANDA-I 2012-2014, Natal, RN, Brazil, 2012

\begin{tabular}{llcc}
\hline \multicolumn{1}{c}{ Nursing diagnosis } & \multicolumn{1}{c}{ Defining characteristic and/or Related factor or Risk factor } & $\mathbf{n}$ & $\%$ \\
\hline 1. Risk of shock & Risk factor: Sepsis & 41 & 100.0 \\
& Risk factor: Hypovolemia & 17 & 41.5 \\
& Risk factor: Hypoxemia & 17 & 41.5 \\
2. Risk of fluid volume imbalance & Risk factor: Sepsis & 41 & 100.0 \\
& & (continue...)
\end{tabular}


Table 3 - (continuation)

\begin{tabular}{|c|c|c|c|}
\hline Nursing diagnosis & Defining characteristic and/or Related factor or Risk factor & $\mathbf{n}$ & $\%$ \\
\hline \multirow[t]{6}{*}{ 3. Gastrointestinal motility dysfunction } & Defining characteristic: increase of gastric residue & 29 & 70.7 \\
\hline & Defining characteristic: Abdominal distension & 21 & 51.2 \\
\hline & Defining characteristic: Regurgitation & 6 & 14.6 \\
\hline & Defining characteristic: Difficulty in eliminating feces & 6 & 14.6 \\
\hline & Defining characteristic: Abdominal pain & 6 & 14.6 \\
\hline & Related factor: Prematurity & 12 & 29.3 \\
\hline \multirow[t]{3}{*}{ 4. Neonatal jaundice } & Defining characteristic: Yellow-orange skin & 26 & 63.4 \\
\hline & Defining characteristic: Abnormal blood profile (hemolysis, serum bilirubin>2mg/dl) & 26 & 63.4 \\
\hline & Related factor: Age of neonate between 1 and 7 days & 26 & 63.4 \\
\hline \multirow[t]{6}{*}{ 5. Impaired gaseous Exchange } & Defining characteristic: Dyspnea & 34 & 82.9 \\
\hline & Defining characteristic: Cyanosis & 25 & 61.0 \\
\hline & Defining characteristic: Hypoxemia & 9 & 22.0 \\
\hline & Defining characteristic: Tachycardia & 7 & 17.1 \\
\hline & Defining characteristic: abnormal arterial $\mathrm{pH}$ & 7 & 17.1 \\
\hline & Related factor: Ventilation-perfusion mismatch & 14 & 34.1 \\
\hline
\end{tabular}

\section{Discussion}

The maternal profile revealed that a significant percentage of the mothers are from cities in the rural parts of the state where the study was held, which is due to the service in the locale where the research took place being a center of excellence in high-risk perinatal care. The mothers' mean age was considered ideal, as it is outside the maternal age ranges of the child at risk at birth ${ }^{(15)}$.

In relation to the variable of pre-natal consultations, a substantial proportion of the mothers had attended less than six consultations, below the number of six which is stipulated by the Ministry of Health(16). One cohort study indicated that attending less than six consultations led to a risk ten times higher of progressing to neonatal sepsis(17).

Among the complications during the pregnancy, UTI was predominant. UTIs are a risk factor for neonatal BSI, as they predispose to the ascending migration of microorganisms to the cervix. This results in preterm labor and birth, low birth weight NBs, premature amniotic membrane rupture and chorioamnionitis ${ }^{(17)}$.

It is known that premature rupture of membranes $(P R O M) \geq 18 \mathrm{~h}$ is an important predictive factor for earlyonset sepsis ${ }^{(2)}$, which represented $14.6 \%$ of the cases, a number within the range observed by other studies(17-18).

The data on prematurity and very low birth weight babies (VLBWB), that is, those whose weight was $\leq 1500 \mathrm{~g}$, endorsed previous studies, which reported rates of sepsis inversely proportional to the weight and to the $\mathrm{GA}^{(19-20)}$. These patients present immunological deficiencies predisposing them to have a risk of infection which is 8 to 11 times greater, when compared to fullterm NBs. The birth weight is a risk factor, above all for late-onset sepsis, as it determines prolonged hospitalization(2,21).

An Apgar score at the 5th minute of $\leq 7$ presented a percentage lower than the results of other studies ${ }^{(17,19)}$. Perinatal asphyxia is understood as a disorder of impaired gaseous exchange which results in fetal hypoxemia and hypercapnia and can predispose to early-onset sepsis, due to neutropenia and to the reduction of medullary reserves of neutrophils ${ }^{(2,20,22)}$.

Concerning the clinical manifestations of the illness, it is appropriate to emphasize the non-specific symptomatic pattern in the neonates. The initial clinical signs may be confused with other illnesses, such as serious congenital heart $\operatorname{defect}^{(2)}$.

In this study, the most common symptoms of BSI in the neonates were respiratory discomfort, lethargy and/or hypoactivity, and intolerance to feeding. This information agrees with the literature only in regard to the respiratory and gastrointestinal symptoms; and other studies report a prevalence of apnea and fever or bradycardia, and hyperglycemia, principally among those below 32 weeks ${ }^{(17,22-23)}$

Five NDs were frequent in more than $60 \%$ of the NBs and belong to the Domains: Safety/protection (Physical injury Class), Nutrition (Hydration and Metabolism Classes) and Elimination and exchange (Gastrointestinal function and Respiratory function Classes)(12). In the authors' view, this data points to the probable health needs to be prioritized in the nursing care plan for NBs with sepsis. The NDs which are little recurrent indicate only individual characteristics of the neonates with the infection.

All the NBs presented the NDs of Risk of Shock and Risk of fluid volume imbalance due to the presence of the 
risk factor "Sepsis"(12). In serious BSI, the clinical picture can culminate in septic shock, resulting in the worsening of the organic dysfunctions, hypotension, metabolic acidosis, oliguria, poor perfusion, and thrombocytopenia(1).

In this study, the Apgar score in the 5th minute $\leq 7$ was related to the triad of NDs: Dysfunctional gastrointestinal motility, Risk of Bleeding, and Risk of Developmental delay.

Perinatal asphyxia causes gastrointestinal effects, such as an increased risk of tissue ischemia and necrotizing enterocolitis ${ }^{(22)}$. In addition to this, it has hematological effects such as disseminated intravascular coagulation (DIC) due to the injury of blood vessels and the low production of coagulation factors and platelets. Depending on the extent of the hypoxemia/hypoxia, the asphyxiated NBs may suffer brain injury, with a risk of delays in neurodevelopment and sequelae in 15 to $45 \%$ of the survivors ${ }^{(22)}$.

More than $70 \%$ of septic extremely premature neonates and VLBWB demonstrate the ND Risk of bleeding. The platelet count increases in line with the GA and the thrombocytopenia (platelets $<100,000 / \mathrm{mm}^{3}$ ) occurs in up to $50 \%$ of the NBs with signs of sepsis and predisposes to DIC and worsening of the picture ${ }^{(2)}$, being an early nonspecific sign of the disease(22).

Among septic NBs with hyperglycemia, 93.3\% and $80 \%$ present the NDs Risk of bleeding and Risk of ineffective renal perfusion, respectively. It is known that hyperglycemia leads to an increase of osmolarity with risk of cerebral hemorrhage, above all in premature $\mathrm{NBs}^{(2)}$.

Among the NBs with progression to septic shock or DIC and death related to sepsis, all presented Reduced cardiac output and Risk of ineffective renal perfusion, and $83.3 \%$ presented the NDs Risk of bleeding and Impaired gaseous exchange. The literature mentions the appearance of cardiovascular dysfunction, acute respiratory distress syndrome, and/or renal, neurological, hematological or hepatic dysfunction in the presence of severe $\mathrm{BSI}^{(1)}$. Thus, the diagnosis must be made at the onset of the picture, as the NBs affected can rapidly progress to septic shock, DIC and death ${ }^{(5)}$. In the light of this, it follows that such NDs indicate a worse clinical picture and a strong relationship with deaths. This assertion, however, needs to be compared with the findings from new correlated studies, for generalizations. The authors infer that the nursing care for the NBs with this infection requires critical reasoning which presupposes the priorities in the care in the more serious situations and assists early decision-making, with a view to reducing deaths related to neonatal sepsis.

\section{Conclusion}

In this study, five NDs predominated in the sample of NBs with neonatal sepsis, distributed in the domains Safety/protection, Nutrition and Elimination and exchange: Risk of shock; Risk of fluid volume imbalance; Dysfunctional gastrointestinal motility; Neonatal jaundice and Impaired gaseous exchange. The NDs found reflected the health needs of the infected neonates and may lead to the formulation of specific nursing care measures within the domains of the NDs.

Various significant relationships were outlined between the different NDs and the neonatal characteristics, which encourage discussion and converge for the generation of new knowledge. However, these relationships deserve to be thoroughly elucidated through further research with greater statistical rigor on the same issue, so as to ascertain if there is significant association between the events reported. Some of the findings could not be grounded on details and compared, due to the absence of similar studies and to the limitation of studies referring to NDs in Neonatology.

Furthermore, the study contributes to strengthening the importance of the nurse's clinical judgment in the clinical practice with the NB with sepsis, with a view to broadening the systematization of nursing care in the neonatal area.

\section{References}

1. Petit JP. Internacional pediatric sepsis consensus conference: Definitions for sepsis and organ dysfunction in pediatrics. Arch Pediatr Urug. [Internet]. 2005 [acesso 13 maio 2012];76(3):254-6. Disponível em: http:// www.sup.org.uy/Archivos/adp76-3/pdf/adp76-3_11.pdf 2. Ministério da saúde (BR). Atenção à saúde do RecémNascido: guia para os profissionais de saúde. Brasília (DF): Ministério da Saúde; 2011. Disponível em: http:// bvsms.saude.gov.br/bvs/publicacoes/atencao_saude_ recem_nascido_profissionais_v2.pdf

3. Agência Nacional de Vigilância Sanitária (ANVISA) (BR). Neonatologia: critérios nacionais de infecção relacionada à assistência à saúde [Internet]. 2010 [acesso 25 jul 2012]. Disponível em: http://portal.anvisa.gov.br/wps/ wcm/connect/aa863580492e0b81b23ab314d16287af/ manual_neonatologia-\%2B03-09-2010-\%2Bnovo. pdf?MOD=AJPERES

4. Gardner SL. Sepsis in the neonate. Crit Care Nurs Clin North Am. [Internet]. 2009. [acesso 3 abril 2012]; 21(1):121-41. Disponível em: http://www.sciencedirect. com/science/article/pii/S0899588508000968 
5. Meireles LA, Vieira AA, Costa CR. Avaliação do diagnóstico da sepse neonatal: uso de parâmetros laboratoriais e clínicos como fatores diagnósticos. Rev Esc Enferm USP. [Internet]. mar 2011 [acesso 3 nov 2012]; 45(1):33-9. Disponível em: http://www. scielo.br/scielo.php?script $=$ sci_arttext $\&$ pid $=$ S0080$62342011000100005 \&$ lng $=$ en $\& n r m=$ iso\&tlng $=$ pt\&ORIG INALLANG Português, Inglês.

6. Lefevre RA. Aplicação do Processo de Enfermagem: promoção do cuidado colaborativo. 5.ed. Porto Alegre: Artmed; 2005. 283 p.

7. Resolução 358, de 15 de outubro de 2009 (COFEN). Dispõe sobre a Sistematização da Assistência de Enfermagem e a implementação do Processo de Enfermagem em ambientes, públicos ou privados, em que ocorre o cuidado profissional de Enfermagem, e dá outras providências [Internet]. 2009. [acesso 30 mai 2013]. Disponível em: http://novo.portalcofen.gov.br/ resoluo-cofen-3582009_4384.html

8. Carvalho EC. Relations between nursing data collection, diagnoses and prescriptions for adult patients at an intensive care unit. Rev. Latino-Am. Enfermagem. 2008;16(4):700-6.

9. Rubarth LB. The Lived Experience of Nurses Caring for Newborns With Sepsis. J Obstet Gynecol Neonatal Nurs. [Internet]. 2003 [acesso 20 dez 2011];32(3):34856. Disponível em: http://www.ncbi.nlm.nih.gov/ pubmed/12774877

10. Cerullo JASB, Cruz DALM. Clinical reasoning and critical thinking $=$ Raciocinio clínico y pensamiento crítico. Rev. Latino-Am. Enfermagem. 2010;18(1):124-9.

11. Lucena AF, Santos CT, Pereira AGS, Almeida MA, Dias VLM, Friedrich MA. Clinical profile and nursing diagnosis of patients at risk of pressure. Rev. Latino-Am. Enfermagem. 2011;19(3):523-30.

12. North American Nursing Diagnosis Association (NANDA International). Diagnósticos de enfermagem da NANDA: definições e classificação 2012-2014. Porto Alegre: Artmed; 2013. 456 p.

13. Alves AMA, Santos IMM, Silva LR. O corpo do recém-nascido: cuidados especiais. In: Figueiredo NMA. Ensinando a Cuidar da Mulher, do Homem e do Recémnascido. São Paulo (SP): Yendis; 2005. p. 315-79. (Série Práticas de Enfermagem, 1).

14. Lima NDC, Silva VM, Beltrão BA. Construção e validação de conteúdo de instrumento de coleta de dados em unidade neonatal. Rev Rene. [Internet]. 2009 [acesso 20 dez 2011];10(3):97-106. Disponível em: http://www. revistarene.ufc.br/revista/index.php/revista/article/ view/542/pdf
15. Ministério da Saúde (BR). Agenda de compromissos para a saúde integral da criança e redução da mortalidade infantil. Brasília: Ministério da Saúde; 2004.

16. Ministério da Saúde (BR). Pré-natal e Puerpério: atenção qualificada e humanizada - manual técnico. Brasília: Ministério da Saúde; 2005. (Série Direitos Sexuais e Direitos Reprodutivos, 5).

17. Pinheiro RS, Ferreira LCL, Brum IR, Guilherme JP, Monte RL. Estudo dos fatores de risco maternos associados à sepse neonatal precoce em hospital terciário da Amazônia brasileira. Rev Bras Ginecol Obstet. [Internet]. 2007. [acesso 15 out 2012]; 29(8):387-95. Disponível em: http://www.scielo.br/scielo.php?script=sci_arttext \&pid $=$ S0100-72032007000800002

18. Trijbels-Smeulders $M$, Jonge GA, Pasker-de Jong PCM, Gerards LJ, Adriaanse AH, VanLingen RA, et al. Epidemiology of neonatal group $B$ streptococcal disease in the Netherlands before and after introduction of guidelines for prevention. Arch Dis Child Fetal Neonatal. [Internet]. 2007. [acesso 15 out 2012]; 92(4):2716. Disponível em: http://www.ncbi.nlm.nih.gov/pmc/ articles/PMC2675425/

19. Herrmann DMML, Amaral LMB, Almeida SC. Fatores de Risco para o Desenvolvimento de Sepse Neonatal Tardia em uma Unidade de Terapia Intensiva. Rev Pediatria. (São Paulo) [Internet]. 2008 [acesso 15 out 2012];30(4):228-36. Disponível em: http://www. pediatriasaopaulo.usp.br/upload/pdf/1269.pdf

20. Stoll BJ, Hansen N, Fanaroff AA, Wright LL, Carlo WA, Ehrenkranz RA, et al. Changes in pathogenes causing early-onset sepsis in very-low-birth-weight infants. N Engl J Med. [Internet]. 2002. [acesso 10 julho 2012];347(4):240-7. Disponível em: http://www.nejm. org/doi/full/10.1056/NEJMoa012657\#t=article

21. Ceccon MEJR. Novas Perspectivas na Sepse Neonatal. Rev Pediatria. (São Paulo) [Internet]. 2008 [acesso 10 jul 2012];30(4):198-202. Disponível em: http://pediatriasaopaulo.usp.br/upload/pdf/1265.pdf 22. Cloherty JP, Eichenwald EC, Stark AR. Manual de Neonatologia. 6.ed. Rio de Janeiro: Guanabara Koogan; 2011. 664 p.

23. Shim GH, Duk Kim S, Suk Kim H, Sun Kim E, Lee HJ, Lee Jin-A. Trends in Epidemiology of Neonatal Sepsis in a Tertiary Center in Korea: A 26-Year Longitudinal Analysis, 1980-2005. J Korean Med Sci. [Internet]. 2011 [acesso 14 jul 2012];26(2):284-9. Disponível em: http://www. ncbi.nlm.nih.gov/pmc/articles/PMC3031016/

Received: Jan. $16^{\text {th }} 2013$ Accepted: Oct. $31^{\text {st }} 2013$ 